\title{
Penyelenggaraan Pemerintah Negeri di Pulau Ambon Kabupaten Maluku Tengah Pasca Berlakunya Undang-Undang Nomor 6 Tahun 2014 Tentang Desa
}

\author{
Natanel Lainsamputty \\ Fakultas Hukum Universitas Pattimura, Ambon, Indonesia \\ E-mail: natanellainsamputty@gmail.com
}

\begin{abstract}
The purpose of this research is to analyze the state regulation in Ambon Island, Central Maluku Regency, to analyze the state Regulation after the enforcement of Act Number 6 of 2014 and analyze why the State is positioned as Adat Law on village administration in Ambon Island, Central Maluku Regency. This research is a normative-empirical legal research using secondary data type that covering three legal materials (primary, secondary and tertiary legal materials) and primary data obtained through interviews of respondents and interviewees. The results of this research indicate the first of the existence of government Negeri in the three districts of Leihitu District, Leihitu West District, and Salahutu District at the Central Maluku Regency in its regulation on preindependence regime retained the original autonomy of the Negeri, but in the post-regime of the Negeri experienced various shifts State intervention is very dominant. Second, the State Regulation on Act Number 6 of 2014 must go through the process of inventory and classification of the existence of the State and determined by the Regional Regulation. Third, the position of the State in the Indonesian state administration system is Adat Law which has the right of autonomy to exercise power as a local self-governing community and local self governing.
\end{abstract}

Keywords: Autonomy; Position; Implementation of Village Administration; Negeri.

\section{A. PENDAHULUAN}

Penjelasan UUD 1945 sebelum diamandemen,menyebutkan adakurang lebih 250 Zelfbesturende Landschappen dan Volksgemenschappen seperti Desa di Jawa dan Bali, Nagari di Minangkabau, Dusun dan Marga di Palembang dan sebagainya. Zelfbesturende landschappen dan Volksgemenschappen tersebut, diakui memiliki susunan asli dan oleh karenanya dapat dianggap sebagai daerah ${ }^{1}$ yang bersifat istimewa. Pada penjelasan yang sama juga ditegaskan bahwa negara menghormati kedudukan daerah-daerah istimewa tersebut dan segala peraturan negara mengenai daerah-daerah itu akan mengingati hakhak asal usul daerah tersebut. ${ }^{2}$

\footnotetext{
${ }^{1}$ Daerah dalam penjelasan Pasal 18 adalah kesatuan masyarakat hukum.

${ }^{2}$ Republik Indonesia, UUD 1945 Pasal 18 dan Penjelasannya.
} 
Sistem pemerintahan desa di Maluku pada rezim adat dikenal dengan Pemerintah Negeri dan umumnya berlaku di Pulau Ambon dan Kabupaten Maluku Tengah. Implementasi pengakuan negara terhadap keberadaan otonomi Negeri maupun kesatuan masyarakat hukum adat yang disebut dengan nama lain sebagai satuan pemerintahan asli yang memiliki otonomi dalam mengatur dan mengurus sendiri kepentingan rakyatnya terjadi pengabaian oleh Pemerintah. Sejarah membuktikan penerapan peraturan perundang-undangan yang berlaku baik pada awal kemerdekaan sampai pada masa orde baru belum mampu menjawab persoalan yang berkaitan dengan kedudukan Negeri di Maluku.

Lahirnya Undang-Undang Nomor 6 Tahun 2014 tentang Desa tidak hanya memberi kepastian hukum bagi desa administratif semata, melainkan juga memberi tempat istimewa bagi desa adat atau yang disebut dengan nama lain. Hal ini terlihat jelas, bahwa UU No. 6 Tahun 2014 mengatur dengan ketentuan khusus yang hanya berlaku untuk desa Adat. Pada Pasal 5 UU No. 6 Tahun 2014, kedudukan desa dinyatakan berada di wilayah kabupaten/kota. Secara lebih lanjut pasal tersebut juga menyatakan sebagai berikut: "Desa berkedudukan di wilayah Kabupaten/Kota". Berdasarkan ketentuan ini, terlihat pergeseran politik hukum mengenai kedudukan Desa. Pada undang-undang terdahulu, Desa dinyatakan sebagai bentukan kabupaten/kota, namun pada UU No. 6 Tahun 2014, Desa tidak dibentuk oleh kabupaten/kota, melainkan hanya dinyatakan berkedudukan baik di kabupaten/kota. Maka dari itu, kedudukan desa pada undangundang yang baru merupakan bentuk pengakuan negara terhadap desa.Dari sisi kewenangan terlihat perkembangan arah politik hukum mengenai kewenangan desa menjadi lebih jelas memperlihatkan otonomi desa. Misalnya, pada Pasal 19 UU No. 6 Tahun 2014 dinyatakan bahwa desa memiliki kewenangan berdasarkan hak asal-usul dan kewenangan lokal berskala desa. Ketentuan mengenai kewenangan berdasarkan hak asalusul memang dapat dijumpai dalam undang-undang terdahulu, tetapi kewenangan lokal berskala desa merupakan kewenangan baru yang memperlihatkan arah politik hukum pemerintahan desa menuju otonomi asli. ${ }^{3}$

UU Nomor 6 Tahun 2014 mengakui keberadaan dua jenis desa, yaitu desa dan desa adat atau disebut dengan nama lain. Sebagaimana disebutkan pada Pasal 6, kedua-duanya merupakan:

“... kesatuan masyarakat hukum yang memiliki batas wilayah yang berwenang untuk mengatur dan mengurus urusan pemerintahan, kepentingan masyarakat setempat berdasarkan prakarsa masyarakat, hak asal usul, dan/atau hak tradisional yang diakui dan dihormati dalam sistem pemerintahan Negara Kesatuan Republik Indonesia".

Sebagaimana diatur lebih lanjut dalam Pasal 97 ayat (1), Bab XIII, Bab khusus tentang Desa Adat, yang menentukan bahwa masyarakat hukum adat yang dapat ditetapkan sebagai Desa Adat itu adalah masyarakat hukum adat yang memenuhi syarat sebagai berikut:

a) kesatuan masyarakat hukum adat beserta hak tradisionalnya secara nyata masih hidup;

b) kesatuan masyarakat hukum adat beserta hak tradisionalnya dipandang sesuai dengan perkembangan masyarakat; dan

${ }^{3}$ Otonomi asli memiliki makna kewenangan pemerintahan Desa dalam mengatur dan mengurus kepentingan masyarakat setempat didasarkan pada hak asal-usul dan nilai-nilai sosial yang ada pada masyarakat setempat.Namun, harus diselenggarakan dalam perspektif administrasi pemerintahan modern. 
c) kesatuan masyarakat hukum adat beserta tradisional sesuai dengan prinsip Negara Kesatuan Republik Indonesia.

Agar masyarakat hukum adat itu dapat ditetapkan sebagai desa adat, Pasal 96 UU Nomor 6 Tahun 2014 mengamanatkan "Pemerintah, Pemerintah Daerah Provinsi, dan Pemerintah Daerah Kabupaten/Kota untuk melakukan penataan kesatuan masyarakat hukum adat". 4 Melalui UU Nomor 6 Tahun 2014, ada perbedaan pada masa sebelum ini, desa adat tidak lagi dilihat sekedar sebagai fakta sosial dan budaya belaka, melainkan 'ditinggikan derajatnya' sebagai 'fakta politik dan hukum'. ${ }^{5}$ Hal ini secara ekplisit dicerminkan oleh diberikannya hak pada desa adat itu untuk 'mengatur dan mengurus pemerintahan dan pembangunan' sebagaimana yang diamanatkan oleh Pasal 6 UU No. 6 Tahun 2014.Negeri merupakan salah satu dari kesatuan masyarakat hukum adat yang memiliki otonomi dalam mengatur dan mengurus kepentingan masyarakatnya sejak Negeri terbentuk berdasarkan asal usul dan adat isitiadat yang ada pada Negeri tersebut. Untuk mempertahankan eksistensi Negeri sebagai kesatuan masyarakat hukum adat, perlu pengaturan yang lebih jelas terhadap kedudukan Negeri dalam sistem ketatanegaraan Indonesia.

Diterapkannya UU No. 6 Tahun 2014 yang mengatur tentang desa adat sangat berpengaruh pada eksistensi Negeri serta kedudukannya dalam sistem ketatanegaraan Indonesia. Oleh karena itu, untuk mempertahankan eksistensi Negeri serta kedudukannya, maka perlu diadakan kajian tentang "Penyelenggaraan Pemerintah Negeri Di Pulau Ambon Kabupaten Maluku Tengah Pasca Berlakunya UU No. 6 Tahun 2014 Tentang Desas"

\section{B. METODE PENELITIAN}

Jenis penelitian dalam penulisan hukum ini adalah penelitian hukum normatif empiris. Data yang dipergunakan dalam penelitian hukum normatif bertumpu pada data sekunder yang bersumber dari bahan hukum primer, bahan hukum sekunder, dan bahan hukum tersier. Bahan hukum primer terdiri dari peraturan perundang-undangan yang berkaitan dengan objek penelitian. Bahan hukum sekunder yang memberikan penjelasan mengenai bahan hukum primer yang berupa buku-buku, artikel, makalah, laporan atau hasil penelitian yang berhubungan dengan objek yang diteliti, sedangkan bahan hukum tersier yaitu bahan yang memberikan petunjuk maupun penjelasan terhadap bahan hukum primer dan bahan hukum sekunder. ${ }^{6}$ Data yang dipergunakan dalam penelitian hukum empiris bertumpu pada data primer yang diperoleh langsung dari sumbernya.Cara dan alat pengumpul data dalam penelitian hukum normatif berbeda dengan penelitian hukum empiris. Cara dan alat pengumpul data dalam penelitian hukum normatif dengan cara penelitian kepustakaan dan alat pengumpul datanya adalah studi kepustakaan, sedangkan dalam penelitian hukum empiris dilakukan dengan cara wawancara dan alat pengumpul datanya berupa pedoman wawancara serta recorder (alat perekam). Data sekunder dan data primer yang diperoleh dari penelitian kepustakaan dan lapangan akan dianalisis secara kualitatif. Metode kualitatif merupakan tata cara penelitian yang menghasilkan

\footnotetext{
${ }^{4}$ Pasal 98 Undang-Undang Nomor 6 Tahun 2014 tentang Desa (Lembaran Negara Republik Indonesia Tahun 2014 Nomor 7, Tambahan Lembaran Negara Republik Indonesia Nomor 5495).

5 Zakaria, R. Yando. (2015), Desa Adat, Nomenklatur Strategis yang Terancam Mandul, Tulisan ini dimungkinkan oleh keterlibatan penulis sebagai short time consultant (STC) pada KOMPAK, Program kerjasama Pemerintah RI dan Pemerintah Australia,. h. 2

${ }^{6}$ Soekanto, Sooerjono dan Mamudji, Sri. (2011), Penelitian Hukum Normatif, Cetakan Ke-13, Jakarta: Raja Grafindo Persada, h. 13.
} 
data deskriptif-analitis ${ }^{7}$ Data yang telah diperoleh kemudian dianalisis secara deskriptif, yaitu memaparkan dan menjelaskan data yang ditemukan dalam penelitian. Adapun pemaparan fakta tersebut dilakukan dengan metode kualitatif, ${ }^{8}$ yaitu metode yang mengungkapkan fakta-fakta secara mendalam berdasarkan karakteristik ilmiah dari individu atau kelompok untuk memahami dan mengungkapkan sesuatu dibalik fenomena.Pendekatan kualitatif menghasilkan data kualitatif, yaitu data yang disajikan dalam bentuk kata atau kalimat.

\section{PEMBAHASAN}

\section{Pengaturan Negeri di Pulau Ambon Kabupaten Maluku Tengah}

\section{a. Rezim Sebelum Kemerdekaan Republik Indonesia}

Salah satu sistem pemerintahan politik tradisional di Indonesia, adalah Negeri, yang merupakan pemerintahan tradisional berbasis pada komunitas masyarakat adat di Maluku. Negeri mempunyai pemerintahan sendiri secara otonom dan berbasis pada masyarakat (self-governing community). Pada rezim adat, setiap Negeri memiliki struktur organisasi pemerintahan Negeri. Susunan pemerintahan Negeri pada pemerintahan Belanda, dimana sistem hukum adat ini ditetapkan dalam keputusan landraad Amboina No.14 Tahun 1919; disebutkan bahwa pemerintah Negeri adalah regent en de kepala soas's. selanjutnya di dalam keputusan landaard Amboina Nomor 30 Tahun 1919 disebutkan bahwa negorijbestuur adalah regent en de Kepala - Kepala Soa, yang berarti bahwa pelaksanaan pemerintahan Negeri dilaksanakan oleh Raja dan Kepala-Kepala Soa. ${ }^{9}$ Negeri di kecamatan leihitu, kecamatan leihitu barat dan kecamatan salahutu pada prinsipnya memiliki sistem pemerintahan Negeri yang sama.

Asshidiqqi menjelaskan kesatuan masyarakat hukum adat merujuk kepada pengertian masyarakat organik yang menjalankan fungsinya melalui organisasi pemerintahannya sebagai instrumen masyarakat adat. ${ }^{10}$ Menurut Sudiyat, Desa dalam pengertian kesatuan masyarakat hukum adat adalah suatu kesatuan kemasyarakatan berdasarkan ketunggalan wilayah yang organisasinya didasarkan atas tradisi yang hidup dalam suasana rakyat dan mempunyai suatu badan tata urusan pusat yang berwibawa di seluruh lingkungan wilayahnya ${ }^{11}$ Pengakuan terhadap sistem pemerintahan Negeri memang sangat dihormati oleh masyarakat adat Maluku, penghormatan ini dikarenakan semua marga/fam/matarumah memiliki fungsi dan peran dalam penyelenggaraan pemerintahan Negeri, masyarakat juga sangat menghargai figur seorang Raja dalam memimpin Negeri, Raja dianggap mampu dalam menyelesaikan persoalan yang ada di dalam masyarakat, dan Raja di percaya sebagai pelindung bagi masyarakat Negeri. Perilaku adat yang terpelihara dan dipertahankan sejak dahulu tetap bertahan hingga kini, diantaranya yang masih kuat, seperti sistim pemerintahan Negeri.

Adapun struktur organisasi pemerintah Negeri di ketiga kecamatan tersebut berdasarkan hasil wawancara dengan para Raja dan tokoh adat ${ }^{12}$ adalah Badan Saniri

\footnotetext{
${ }^{7}$ Soekanto, Soerjono. (1981), Pengantar Penelitian Hukum, Jakarta: Penerbit Universitas Indonesia, h. 250 .

${ }^{8}$ Ali, Zainuddin. (2014), Metode Penelitian Hukum, Cetakan Ke-V, Jakarta: Sinar Grafika, h. 107.

${ }^{9}$ Effendi, Ziwar. (1987), Hukum Adat Ambon-Lease, Jakarta: Pradnya Paramita, h. 40 77-78

${ }^{10}$ Asshidiqqi, Jimly, 2006, Hukum Acara Pengujian Undang-Undang, Jakarta: Konstitusi Press h.

11 Sudiyat, (1981), Hukum Adat, Yogyakarta: Liberti, h.142

12 Wawancara dengan Para Raja dan Tokoh Adat pada 12 oktober s/d 11 November 2016
} 
Rajapatti yang terdiri dari Raja dan Kepala-Kepala Soa, Badan ini kedudukannya sebagai badan eksekutif dibawah pimpinan Raja. Raja harus berasal dari turunan matarumah/keturunan yang menurut hukum adat berhak menyandang gelar yang dalam bahasa adat disebut Upu Latu, Saniri Negeri yang merupakan kumpulan wakilwakil Soa yaitu suatu kelompok masyarakat yang terdiri dari beberapa marga atau matarumah (adat) yang memilih dan mengangkat salah satu anggotanya sebagai wakil pada Saniri Negeri dan 1 (satu) orang sebagai Kepala Soa. Kedudukan Saniri Negeri sebagai badan legislative.

Selain Badan Saniri Rajapatti dan Saniri Negeri pelaksanaan pemerintahan Negeri juga terdiri dari para tua-tua adat dan tokoh-tokoh masyarakat yang berpengaruh seperti tokoh agama (pendeta/imam), Kewang, Kapitan, Marinyo, Malesi, Tuan Negeri. Negeri juga mempunyai badan musyawara yang disebut dengan Badan Saniri Besar. Lembagalembaga adat yang terdapat dalam struktur Pemerintahan Negeri adat ini memiliki fungsi dan peranan yang sangat besar terhadap kelangsungan pembangunan masyarakat.

\section{b. Rezim Setelah Kemerdekaan}

Pengaturan otonomi Negeri berdasarkan susunan asli mengalami perubahan ketika Orde Baru berkuasa, kehidupan demokrasi lokal Negeri tradisional yang telah berlangsung turun temurun tersebut, kemudian seketika mengalami perubahan, melalui Undang-undang No 5 Tahun 1979 tentang Pemerintahan Desa, pemerintahan Negeri sengaja dihapuskan dan diganti dengan pemerintahan desa.Pada era reformasi, menyusul lahirnya Undang-undang Nomor 22 Tahun 1999, posisi desa juga belum tegas meski undang-undang itu mengakui keberagaman desa-desa di Indonesia.Tetapi persoalan dasarnya bukan terletak pada keragaman desa, tetapi pada posisi dan kewenangan desa. Selanjutnya lahir UU No. 32 Tahun 2004 tentang Pemerintahan Daerah menggantikan UU No. 22 Tahun 1999 yang memosisikan pemerintah Desa sebagai bagian dari pemerintah kabupaten/kota, sehingga kedudukan desa dalam UU No. 32 Tahun 2004 berimplikasi pada kewenangan yang dimiliki desa. Desa hanya menjalankan kewenangan dari pemerintahan di atasnya, bukan melaksanakan kewenangan yang berdasar pada kebutuhan desa. ${ }^{13}$

Berlakunya UU No. 32 Tahun 2004, telah melahirkan Peraturan Daerah Provinsi Maluku Nomor 14 Tahun 2005 Tentang Penetapan Kembali Negeri Sebagai Kesatuan Masyarakat Hukum Adat Dalam Wilayah Pemerintahan Provinsi Maluku dan Peraturan Daerah Kabupaten Maluku Tengah Nomor 1 Tahun 2006 Tentang Negeri belum menjawab persoalan kedudukan Negeri dalam sistem ketatanegaraan Indonesia, hal ini disebabkan belum dilakukannya pengaturan terhadap keberadaan kepemilikan wilayah petuanan dari suatu Negeri yang diakui, hak-hak yang ada di dalam wilayah petuanan dimaksud, penyelenggaraan pemerintahan adat dan kelembagaan adat yang mendukung penguasaan wilayah dan hak-hak adat. Pengaturan tersebut jelas menjadikan otonomi berhenti di kabupaten/kota. Konsekuensinya, pengaturan lebih lanjut tentang Desa dilakukan oleh kabupaten/kota, sehingga kewenangan Desa adalah kewenangan kota yang diserahkan kepada Desa. ${ }^{14} \mathrm{Hal}$ mengakibatkan asas rekognisi terhadap otonomi Desa berdasarkan hak asal usul dan hak tradisionalnya menjadi tidak jelas.

Berdasarkan data penelitian ditemukan sebagian besar Negeri di Pulau Ambon

13 Yasin, Muhammad. dkk, (2014), Anotasi Undang-Undang No. 6 tahun 2014 tentang Desa, Jakarta: Diterbitkan oleh: Pusat Telaah dan Informasi Regional, h.39.

${ }^{14}$ Ibid, h. 37-38 
Kabupaten Maluku Tengah masih dipimpin oleh Penjabat Raja yang ditunjuk langsung oleh Bupati. Data yang diperoleh di Kecamatan Leihitu Barat dari 5 (lima) Negeri hanya 2 (dua) Negeri yang dipimpin oleh Raja dari keturunan yang berhak, sedangkan 3 (tiga) Negeri masih dipimpin oleh Pejabat Raja yang di tunjuk oleh Bupati Maluku Tengah. ${ }^{15}$ Kecamatan Leihitu terdapat 11 (sebelas) Negeri dan hanya 5 (lima) Negeri yang di pimpin oleh Raja, sedangkan 6 (enam) Negeri masih di pimpin oleh Pejabat Raja. ${ }^{16}$ Kecamata Salahutu dari 6 (enam) Negeri masih dipimpin oleh Pejabat Raja. Kekosongan kepemimpinan dari tokoh adat berakibat perlahan keberadaan Negeri sebagai masyarakat hukum adat menjadi hilang.

\section{c. Pengaturan Negeri Pasca Berlakunya UU No. 6 Tahun 2014 Tentang Desa}

Pemerintah Daerah hingga saat ini dengan diterbitkannya UU No 6 tahun 2014 tentang Desa yang mana menegaskan dengan memberikan keleluasaan kepada desa untuk dapat lebih mengatur rumah tangganya sendiri sesuai dengan kondisi adat dan budaya setempat. Undang-undang tersebut selanjutnya dipertegas dalam Peraturan Pemerintah Nomor 43 tahun 2014 yang memuat tentang pelaksanaan Undang-undang tentang Desa tersebut. Dari kewenangan yang dimiliki oleh desa diharapkan dalam pelaksanaannya sesuai dengan tujuan, yaitu mewujudkan otonomi desa dimana desa dapat mandiri. ${ }^{17}$

Pengaturan Negeri pasca berlakunya UU No 6 Tahun 2014 sesuai dengan Pasal (96) menyebutkan "Pemerintah, Pemerintah Daerah Provinsi, dan Pemerintah Daerah Kabupaten/Kota melakukan penataan kesatuan masyarakat hukum adat dan ditetapkan menjadi Desa Adat".selanjutnya dalam Pasal 29 PP No 43 Tahun 2014 menyebutkan:

1) Pemerintah daerah kabupaten/kota melakukan inventarisasi Desa yang ada di wilayahnya yang telah mendapatkan kode Desa.

2) Hasil inventarisasi Desa sebagaimana dimaksud pada ayat (1) dijadikan dasar oleh pemerintah daerah kabupaten/kota untuk menetapkan Desa dan Desa adat yang ada di wilayahnya.

3) Desa dan Desa adat sebagaimana dimaksud pada ayat (2) ditetapkan dengan peraturan daerah kabupaten/kota.

Ketentuan lebih lanjut diatur dalam Pasal 30 PP No 43 Tahun 2014 dalam menyebutkan:

1) Penetapan desa adat dilakukan dengan mekanisme:

a) pengidentifikasian Desa yang ada; dan

b) pengkajian terhadap desa yang ada yang dapat ditetapkan menjadi desa adat.

2) Pengidentifikasian dan pengkajian sebagaimana dimaksud pada ayat (1) dilakukan pemerintah daerah provinsi dan pemerintah daerah kabupaten/kota bersama majelis adat atau lembaga lainnya yang sejenis.

Sesuai ketentuan pasal tersebut maka pengaturan Negeri pasca berlakunya UU Nomor 6 tahun 2014 harus melalui proses penetapan berdasarkan hasil inventarisasi, pengidentifikasian dan pengkajian desa yang dilakukan oleh pemerintah daerah provinsi dan pemerintah daerah kabupaten/kota bersama majelis adat. Penetapan Desa Adat diatur

\footnotetext{
${ }^{15}$ Data diambil pada Negeri di Kecamatan Leihitu Barat, tanggal 12-19 oktober 2016.

${ }^{16}$ Data diambil pada Negeri di Kecamatan Leihitu, tanggal 20-25 oktober 2016.

${ }^{17}$ Ibid, h 119.
} 
dalam Pasal 31 PP No 43 Tahun 2014 yang menyebutkan:

1) Bupati/walikota menetapkan desa adat yang telah memenuhi syarat berdasarkan hasil identifikasi dan kajian sebagaimana dimaksud dalam Pasal 30.

2) Penetapan desa adat sebagaimana dimaksud pada ayat (1) dituangkan dalam rancangan peraturan daerah.

3) Rancangan peraturan daerah sebagaimana dimaksud pada ayat (2) yang telah disetujui bersama dalam rapat paripurna dewan perwakilan rakyat daerah kabupaten/kota disampaikan kepada gubernur untuk mendapatkan nomor register dan kepada Menteri untuk mendapatkan kode desa.

4) Rancangan peraturan daerah yang telah mendapatkan nomor register dan kode desa sebagaimana dimaksud pada ayat (3) ditetapkan menjadi peraturan daerah.

Penetapan Negeri dengan peraturan daerah harus mempertimbangkan keberadaan Negeri sebagai kesatuan masyarakat hukum adat yang sesuai dengan bunyi Pasal 96 UU No. 6 tahun 2014 harus memenuhi syarat:

a) Kesatuan masyarakat hukum adat beserta hak tradisionalnya secara nyata masih hidup, baik yang bersifat teritorial, genealogis, maupun yang bersifat fungsional;

b) Kesatuan masyarakat hukum adat beserta hak tradisionalnya dipandang sesuai dengan perkembangan masyarakat; dan

c) Kesatuan masyarakat hukum adat beserta hak tradisionalnya sesuai dengan prinsip Negara Kesatuan Republik Indonesia.

Pasal 1 ayat 7 UU No. 12 Tahun 2011 tentang Pembentukan Peraturan PerundangUndangan (Lembaran Negara Republik Indonesia Tahun 2011 Nomor 82, Tambahan Lembaran Negara Republik Indonesia Nomor 5234, selanjutnya disingkat UU No. 12 Tahun 2011) menegaskan bahwa:

"Peraturan Daerah Provinsi adalah Peraturan Perundang-undangan yang dibentuk oleh Dewan Perwakilan Rakyat Daerah Provinsi dengan persetujuan bersama Gubernur".

Selanjutnya Pasal 1 ayat 8 UU No. 12 Tahun 2011 menegaskan pula bahwa:

"Peraturan Daerah Kabupaten/Kota adalah Peraturan Perundang-undangan yang dibentuk oleh Dewan Perwakilan Rakyat Daerah Kabupaten/Kota dengan persetujuan bersama Bupati/Walikota".

Dalam hal materi muatan yang harus diatur dalam pembentukan peraturan daerah, Pasal 14 UU No. 12 Tahun 2011 menentukan bahwa:

"Materi muatan Peraturan Daerah Provinsi dan Peraturan Daerah Kabupaten/Kota berisi materi muatan dalam rangka penyelenggaraan otonomi daerah dan tugas pembantuan serta menampung kondisi khusus daerah dan/atau penjabaran lebih lanjut Peraturan Perundang-undangan yang lebih tinggi”.

Ditetapkannya Negeri dengan Peraturan Daerah, maka Pemerintah daerah kabupaten/kota dapat mengatur penyelenggaraan pemerintahan Negeri sesuai dengan otonomi asli Negeri dan tidak terlepas dari persyaratan yang di sebutkan dalam UU Nomor 6 Tahun 2014. Eksistensi masyarakat adat Maluku memang tidak perlu dipersoalkan, hanya saja sebagai jati diri (volkgeist) orang Maluku, justfikasinya melalui 
proses legislasi ke dalam bentuk produk peraturan daerah perlu ditempuh. Ini sangat beralasan, sebab dari perspektif hak asasi manusia, eksistensi demikian baru merupakan pengakuan sebagai hak negative (negativerights), namun di dalam kehidupan bermasyarakat, berbangsa dan bernegara dalam bingkai NKRI pengakuan dan pengaturannya sebagai hukum positif (positif rights) melalui peraturan perundangundangan bertujuan untuk memberikan kepastian hukum dan keadilan.

\section{Posisi Negeri Sebagai Desa Adat dalam Penyelenggaraan Pemerintahan Desa di Pulau Ambon Kabupaten Maluku Tengah}

Penyelenggaraan pemerintahan desa yang disusun melalui UU Nomor 6 Tahun 2014 memberikan pengaturan hubungan yang lebih tegas dan jelas antara desa dengan pemerintah pusat dan desa dengan pemerintah daerah.Konsep Pemerintahan desa menurut UU No. 6 Tahun 2014 tidak terlepas dari penafsiran terhadap Pasal 18 B ayat (2) UUD NRI Tahun 1945 yang menyebutkan:

"Negara mengakui dan menghormati kesatuan-kesatuan masyarakat hukum adat beserta hak-hak tradisionalnya sepanjang masih hidup dan sesuai dengan perkembangan masyarakat dan prinsip Negara Kesatuan Republik Indonesia, yang diatur dalam undang-undang".

Menurut tafsir pasal ini, Sejarah membuktikan bahwa setiap komunitas lokal atau masyarakat adat yang tersebar di seluruh penjuru Indonesia mempunyai pemerintahan sendiri (selfgoverning community) yang bersifat tradisional lokalitsik dan mengontrol tanah ulayat secara otonom. Berdasarkan perspektif ini self governing community, apabila disesuaikan dengan penjelasan UUD 1945 menyebutkan "Dalam teritorial Negara Indonesia, terdapat kurang lebih 250 zelbestuurende landschappen dan volksgemeenschappen, seperti Desa di Jawa dan Bali, Nagari di Minangkabau, Dusun di Palembang, dan sebagaianya. Daerah-daerah itu mempunyai susunan asli dan karenanya dapat dianggap sebagai daerah istimewa.Negara Republik Indonesia menghormati kedudukan daerah-daerah istimewa tersebut dan segala peraturan negara yang mengenai daerah itu dengan mengingat hak asal-usul daerah tersebut. ${ }^{18}$ Pada prinsipnya Pasal $18 \mathrm{~B}$ ayat (2) UUD NRI Tahun 1945, konsep self governing community ditegaskan sebagai kesatuan masyarakat hukum adat yang diakui dan dihormati keberadaannya oleh negara. ${ }^{19}$ Ketentuan pasal 18 B ayat (2) UUD NRI Tahun 1945 merupakan bagian dari Bab VI tentang Pemerintahan Daerah.Noscitur a socis, yaitu arti suatu perkataan harus dinilai dari ikatannya dalam kumpulan-kumpulannya. ${ }^{20}$ Pasal 18 B ayat (2) UUD NRI Tahun 1945 tidak hanya ditafsirkan sebagai kesatuan masyarakat hukum adat (self governing community), tetapi merupakan kesatuan pengaturan tentang Pemerintahan Daerah (local self government).

Berdasarkan penafsiran pasal 18 UUD NRI Tahun 1945, maka ketentuan Pasal 5 UU No. 6 Tahun 2014 menyebutkan "Desa berkedudukan di wilayah Kabupaten/Kota", pada penjelasannya Desa yang berkedudukan di wilayah Kabupaten/Kota dibentuk dalam sistem pemerintahan negara.Mengacu pada klausulnya, posisi Desa semata-mata hanya bagian kewilayahan dari suatu daerah yang disebut kabupaten atau kota. Posisi ini

\footnotetext{
${ }^{18}$ Undang-Undang Dasar Negara Republik Indonesia Tahun 1945.Jakarta : Sekretariat Jenderal MPR RI. 2012, h. 36.

19 Asshiddiqie, Jimly. (2015), Konstitusi Masyarakat Desa (Piagam Tanggung Jawab Dan Hak asasi Warga Desa). PDF, h. 2

${ }^{20}$ Ibid, h. 98
} 
diperkuat juga dengan UU No. 23 Tahun 2014 tentang Pemerintahan Daerah yang juga meletakkan Desa semata-mata bagian kewilayahan dari suatu daerah yang disebut dengan kecamatan. Kedua undang-undang tersebut tidak mendudukkan Desa sebagai bagian dari pemerintahan di atasnya.

Posisi Negeri sesuai dengan UU No. 6 Tahun 2014 telah mengangkat Negeri pada posisi subyek yang terhormat dalam ketatanegaraan Republik Indonesia. Selain itu, pengaturan desa juga akan menentukan format desa yang tepat sesuai dengan konteks keragaman lokal. Penguatan kemandirian desa melalui Undang-Undang tentang Desa sebenarnya juga menempatkan Desa sebagai subyek pemerintahan dan pembangunan yang betul-betul berangkat dari bawah (bottom-up) ". ${ }^{21}$ Penyelenggaraan pemerintahan desa di Kecamatan Leihitu, Kecamatan Leihitu Barat, dan Kecamatan Salahutu Kabupaten Maluku Tengaht, jika dilihat dari sistim penyelenggaraan pemerintahan Negeri sesuai dengan pembahasan pertama, Negeri mengenal pembagian kekuasaan yaitu kekuasaan eksekutif (Pemerintah Negeri) dimana Raja memiliki fungsi sebagai kepala pemerintahan dan sebagai kepala adat, selanjutnya kekuasaan legislatif yaitu Badan Saniri Negeri dan kekuasaan yudikatif seperti Badan Saniri Lengkap yang bertugas menjadi institusi peradilan lokal (penyelesaian konflik lokal, bukan pidana). Perkembangan penyelenggaraan pemerintahan Negeri yang otonom akan lebih baik dipahami bukan semata-mata otonomi asli, bukan semata dalam bentuk self governing community, bukan pula terpaku pada kemandirian desa yang berlandaskan pada mobilisasi swadaya masyarakat. Seperti halnya otonomi daerah, otonomi Negeri harus dipahami sebagai local self government yaitu pemerintah Negeri yang mempunyai kedudukan dan kewenangan yang identik dengan daerah otonom yang mempunyai hak dan peluang untuk mengembangkan diri dan mengejar ketinggalan dengan tetap memperhatikan nilai-nilai setempat/lokal yang positif dan kondusif. ${ }^{22}$ Negeri yang otonom tentunya bukan berarti sekedar unit pemerintahan yang berada pada subsistem Kabupaten/Kota, melainkan sebagai entitas daerah kecil yang diakui dan menjadi bagian dari negara. Negeri otonom sebagai local self government itu tentu membutuhkan desentralisasi dari negara, yakni pembagian kewenangan, sumber daya dan tanggung jawab kepada Negeri. Prinsip dasar desentralisasi sesuai dengan penafsiran ketentuan Pasal 18 UUD NRI Tahun 1945 adalah Negara Kesatuan Republik Indonesia dibagi menjadi daerah provinsi, daerah kabupaten/kota dan desa yang masing-masing daerah itu mempunyai hak, kewenangan, sumber daya dan tanggung jawab dalam pengelolaan pemerintahan.

\section{PE N U T U P}

Pengaturan Negeri di Pulau Ambon Kabupaten Maluku tengah pada rezim sebelum kemerdekaan tetap mempertahankan sistim pemerintahan sesuai dengan otonomi asli Negeri. Pada perkembangannya Kedudukan Negeri menjadi terabaikan, Negeri tidak diberikan kewenangan yang penuh dalam mengatur dan mengurus rumah tangganya sendiri. Pengaturan Negeri pasca berlakunya UU No 6 tahun 2014 dilakukan dengan penataan kesatuan masyarakat hukum adat dan ditetapkan menjadi Desa dan Desa Adat oleh Pemerintah, Pemerintah Daerah Provinsi, dan Pemerintah Daerah Kabupaten/Kota.

Posisi Negeri sebagai Desa Adat berdasarkan Ketentuan pasal 18 B ayat (2) UUD NRI Tahun 1945 merupakan bagian dari Bab VI tentang Pemerintahan Daerah. Sehingga

${ }^{21}$ Gamawan Fauzi dalam paparannya di depan rapat Pansus pada 4 April 2012

${ }^{22}$ Ibid, h. 45 
Pasal 18 B ayat (2) UUD NRI Tahun 1945 tidak hanya ditafsirkan sebagai kesatuan masyarakat hukum adat (self governing community), tetapi merupakan kesatuan pengaturan tentang Pemerintahan Daerah (local self government). Posisi Negeri sesuai dengan UU No. 6 Tahun 2014 telah mengangkat Negeri pada posisi subyek yang terhormat dalam ketatanegaraan Republik Indonesia. Berdasarkan sistim pemerintahan Negeri, maka sangat tepat jika Negeri diposisikan sebagai desa adat, yang menggabungkan antara skema local self government dan selfgoverning community. Perkembangan penyelenggaraan pemerintahan Negeri yang otonom akan lebih baik dipahami bukan semata-mata otonomi asli, bukan semata dalam bentuk self governing community, bukan pula terpaku pada kemandirian desa yang berlandaskan pada mobilisasi swadaya masyarakat. Penguatan kemandirian desa melalui Undang-Undang tentang Desa telah menempatkan Desa sebagai subyek pemerintahan dan pembangunan yang betul-betul berangkat dari bawah (bottom-up).

\section{DAFTAR PUSTAKA}

\section{Buku}

[1] A.A.G.N. Ari Dwipayana dan Eko, Sutoro. Pokok-Pokok Pikiran Untuk Penyempurnaan UU No. 32 Tahun 2004 Khusus Pengaturan tentang Desa, Yogyakarta: IRE Press.

[2] Arenawati, (2014), Administrasi Pemerintahan Daerah, Sejarah, konsep dan penatalaksanaan diIndonesia, Yogjakarta: Graha Ilmu.

[3] Asshidiqqi, Jimly. (2006), Hukum Acara Pengujian Undang-Undang, Jakarta: Konstitusi Press.

[4] Eko, Sutoro (Ed.), (2003). Manifesto Pembaharuan Desa, Yogyakata: APMD Press.

[5] Ali, Zainuddin. (2014), Metode Penelitian Hukum, Cetakan Ke-V, Jakarta: Sinar Grafik.

[6] Effendi, Ziwar. (1987), Hukum Adat Ambon-Lease, Jakarta: penerbit : Pradnya Paramita.

[7] Soekanto, Sooerjono, (1981), Pengantar Penelitian Hukum, Jakarta: Penerbit Universitas Indonesia.

[8] Sudiyat, (1981), Hukum Adat, Yogyakarta: Liberti.

[9] Yasin, Muhammad. dkk, (2014), Anotasi Undang-Undang No. 6 tahun 2014 tentang Desa, Jakarta: Pusat Telaah dan Informasi Regional.

\section{Jurnal dan Lain-Lain}

[10]Zakaria, Yando R. (2015), Desa Adat, Nomenklatur Strategis yang Terancam Mandul, Kompak. 